\title{
Human 3 beta-hydroxysteroid dehydrogenase deficiency associated with normal spermatic numeration despite a severe enzyme deficit
}

\author{
Bruno Donadille', Muriel Houang², Irène Netchine ${ }^{2,3}$, Jean-Pierre Siffroi ${ }^{3,4}$ and Sophie Christin-Maitre ${ }^{1,3,4}$ \\ 'Service d'Endocrinologie et Médecine de la Reproduction, Centre de Référence des Maladies Endocrines Rares de la Croissance, Hôpital Saint Antoine, \\ Groupe Hospitalier Universitaire Est, AP-HP, Paris, France \\ ${ }^{2}$ Service d'Explorations Fonctionnelles Endocriniennes, Centre de Référence des Maladies Endocrines Rares de la Croissance, Hôpital Trousseau, Groupe \\ Hospitalier Universitaire Est, AP-HP, Paris, France \\ ${ }^{3}$ Université Pierre et Marie Curie, Sorbonne Université, Paris, France \\ ${ }^{4}$ INSERM UMR_S933, Paris, France
}

Correspondence should be addressed to B Donadille: bruno.donadille@aphp.fr

\begin{abstract}
Human 3 beta-hydroxysteroid dehydrogenase deficiency (3b-HSD) is a very rare form of congenital adrenal hyperplasia resulting from HSD3B2 gene mutations. The estimated prevalence is less than 1/1,000,000 at birth. It leads to steroidogenesis impairment in both adrenals and gonads. Few data are available concerning adult testicular function in such patients. We had the opportunity to study gonadal axis and testicular function in a 46,XY adult patient, carrying a HSD3B2 mutation. He presented at birth a neonatal salt-wasting syndrome. He had a micropenis, a perineal hypospadias and two intrascrotal testes. HSD3B2 gene sequencing revealed a 687 del27 homozygous mutation. The patient achieved normal puberty at the age of 15 years. Transition from the paediatric department occurred at the age of 19 years. His hormonal profile under hydrocortisone and fludrocortisone treatments revealed normal serum levels of $17 \mathrm{OH}$-pregnenolone, as well as SDHEA, ACTH, total testosterone, inhibin B and AMH. Pelvic ultrasound identified two scrotal testes of $21 \mathrm{~mL}$ each, without any testicular adrenal rest tumours. His adult spermatic characteristics were normal, according to WHO 2010 criteria, with a sperm concentration of $57.6 \mathrm{million} / \mathrm{mL}(N>15), 21 \%$ of typical forms $(N>4 \%)$. Sperm vitality was subnormal $(41 \% ; N>58 \%)$. This patient, in contrast to previous reports, presents subnormal sperm parameters and therefore potential male fertility in a 24-years-old patient with severe 3b-HSD deficiency. This case should improve counselling about fertility of male patients carrying HSD3B2 mutation.
\end{abstract}

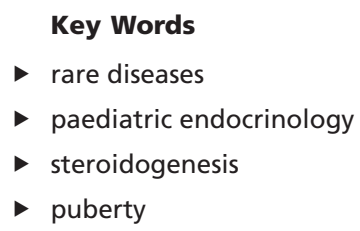

Endocrine Connections (2018) 7, 395-402

\section{Introduction}

Human 3beta-hydroxysteroid dehydrogenase deficiency (3b-HSD) is a very rare form of congenital adrenal hyperplasia resulting from HSD3B2 gene mutations (ORPHA90791) (1). Sixty-one unrelated families have been published since the first report in 1962. The prevalence of autosomal recessive HSD3B2 mutations is less than 1/1,000,000 in humans (ORPHA90791) (2).
In France, during an 8-year study period (1996-2003), only four cases of 3b-HSD2 deficiency have been detected among 6,012,798 neonatal screening tests (3). HSD3B2 gene is located on chromosome 1q13.1, and it encodes for the human type II (3b-HSD2) isoenzyme, which is only expressed in the adrenal cortex and in steroidogenic cells within the gonads. The isoenzyme 3b-HSD2 is an essential
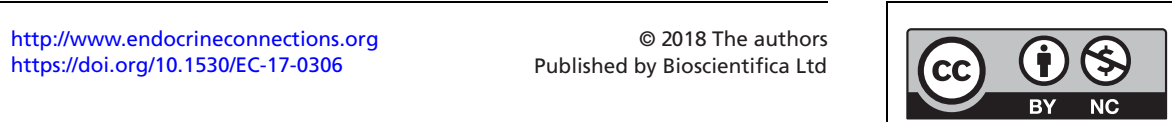

This work is licensed under a Creative Commons Attribution-NonCommercial 4.0 International License. 
A second isoenzyme, the human type I isoenzyme (3b-HSD1), encoded by the HSD3B1 gene, is expressed in the placenta and peripheral tissues, such as breast, liver and brain (3). To our knowledge, no mutation of HSD3B1 gene has been reported in humans (4).

Data concerning the natural history of patients with HSD3B2 gene mutations are scarce. Few detailed hormonal evaluations or sperm analysis have been reported in such patients. Furthermore, they mainly concern patients with moderate DSD. We describe an adult patient carrying a dihydrotestosterone plasma levels in 46,XY foetuses (3).

\section{Periphery}

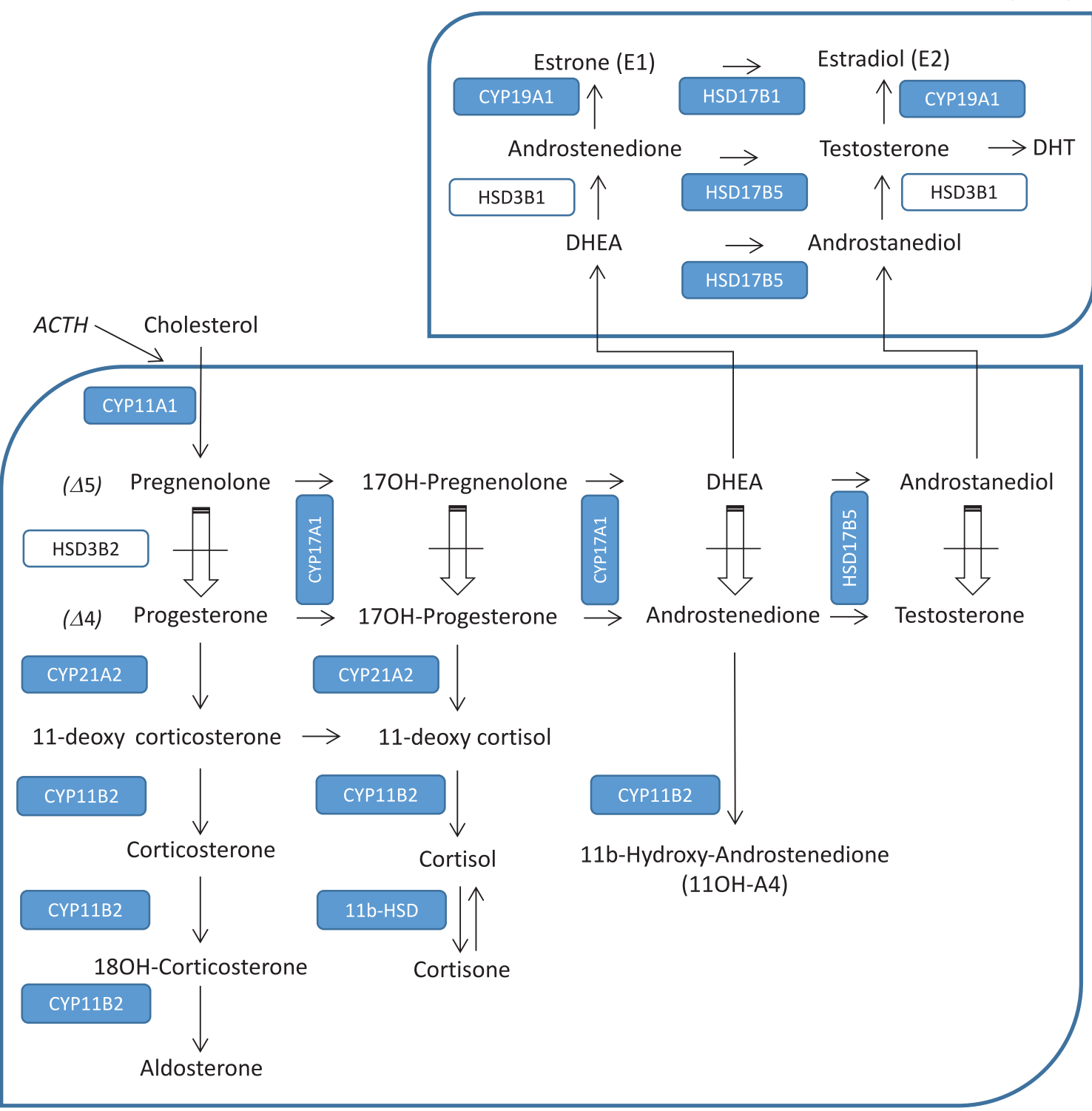

\section{Adrenals and Leydig cells}

Figure 1

Adrenal and gonadic steroidogenesis pathway. Mutated HSD3B2 enzyme prevents the Delta 5 to Delta 4 conversion pathway, inducing a dramatically low DHEA/D4-dione conversion.

$\begin{array}{lr}\text { http://www.endocrineconnections.org } & \text { () } 2018 \text { The authors } \\ \text { https://doi.org/10.1530/EC-17-0306 } & \text { Published by Bioscientifica Ltd }\end{array}$

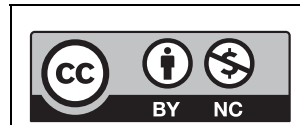

This work is licensed under a Creative Commons Attribution-NonCommercial 4.0 International License. 
c.687del27 HSD3B2 homozygous mutation and report normal or subnormal sperm parameters, although this patient carries a severe mutation.

\section{Subject and methods}

The patient presented with a salt-wasting crisis 12 days after birth. He was referred to Trousseau paediatric hospital (Assistance Publique - Hôpitaux de Paris, France). He had a micropenis, two palpable intrascrotal testes and a perineal hypospadias. Hormonal workup showed a 17OH-progesterone (17OH-P) plasma level contrasting with an elevated 17OH-pregnenolone (17OH-Preg), suggesting a 3b-HSD deficiency (Fig. 1). This patient's phenotype at birth has been previously reported by Moisan and coworkers (5). HSD3B2 gene sequencing revealed a $687 \mathrm{del} 27$ homozygous mutation, defined as a 27-bp deletion in exon IV, deleting the terminal base pair of codon 229 and the entire codons 230-237, in addition to the first two base pairs of codon 238. Functional in vitro activity of the mutant enzyme was dramatically low. His karyotype was $46, \mathrm{XY}$. His elder sister had died at birth in Sri Lanka, most probably from salt wasting. Both parents were found to be heterozygous for the same mutation. The perineal hypospadias was surgically corrected at the age of 2 years. The patient has been followed on a yearly basis, from birth to the age of 19 years in Trousseau's paediatric hospital, and he was then transferred to our adult unit, in Saint Antoine Hospital, Paris, France. The study was approved by the Clinical Research and Development Department of Assistance PubliqueHôpitaux de Paris. It was conducted as part of usual patient care and performed according to the French Bioethics law. The patient was fully informed and gave his written consent for the study.

Morning samples for steroids, FSH, LH and inhibin $\mathrm{B}, \mathrm{AMH}$ were sent to the accredited (Cofrac: www. cofrac.fr) clinical endocrinology laboratories in Saint Antoine and Cochin hospitals respectively. These laboratories participate in the French national quality control programme for steroid and peptide hormone immunoassays (ProBioQual: https://www.probioqual. $\mathrm{com} /$ ). Inter-assay coefficients of variation were below $8.5 \%$. Radioimmunoassay (RIA) technology after celite chromatographic purification of $1-2 \mathrm{~mL}$ of extracted serum was used, as previously described $(6,7)$. Inhibin B was measured by means of a solid-phase sandwich assay using Oxford Bioinnovation reagents (Diagnostic Systems Laboratories, distributed by Beckman-Coulter, Villepinte,

$\begin{array}{lr}\text { http://www.endocrineconnections.org } & \text { ( } 2018 \text { The authors } \\ \text { https://doi.org/10.1530/EC-17-0306 } & \text { Published by Bioscientifica Ltd }\end{array}$

France) (8). AMH was measured by a solid-phase sandwich assay as previously described using Oxford Bioinnovation reagents (Diagnostic Systems Laboratories, distributed by Beckman-Coulter) (8).

Plasma steroids evaluations have been performed using liquid chromatography-mass spectrometry (LC-MS/MS), which allows steroid hormone analysis of sixteen analytes from a single sample in $150 \mu \mathrm{L}$ of serum, as previously described $(6,7,9)$.

Semen was obtained after 4 days withdrawal, at the age of 24 years. Sperm concentration, motility as well as sperm morphology were evaluated according to WHO criteria (10).

\section{Results}

A detailed family history revealed consanguinity, as shown in Fig. 2. At the age of 19 years, the patient's final height was $170 \mathrm{~cm}$ (target height: $164 \mathrm{~cm}$ ), his weight $63 \mathrm{~kg}$ and his body mass index (BMI) $22 \mathrm{~kg} / \mathrm{m}^{2}$. His body surface area was $1.73 \mathrm{~m}^{2}$. His blood pressure was $110 / 60 \mathrm{mmHg}$, and he did not present any orthostatic hypotension. He was taking daily $30 \mathrm{mg}$ of hydrocortisone $\left(17.3 \mathrm{mg} / \mathrm{m}^{2} /\right.$ day $)$ and $75 \mu \mathrm{g}$ of fludrocortisone. At the age of 20 years, he travelled back to Sri Lanka and did not present any acute adrenal insufficiency. A prophylactic $100 \mathrm{mg}$ hydrocortisone injection has only once been administrated during his lifetime, in a context of hand surgery after a minor trauma at the age of 24 years. The main complaint of the patient concerned his micropenis, as the penile length was $4 \mathrm{~cm}$. Gynaecomastia was not present. Both testes were intrascrotal, with a volume of $20 \mathrm{~mL}$, each $(N: 15-20 \mathrm{~mL})$. Testicular ultrasound revealed two testes without any evidence of testicular adrenal rest tumours (TART). No suspect testicular mass was detected. His bone density was normal with a femoral $T$-score of +2.8 s.D. and vertebral $T$-score of +1.9 s.D. His plasma parameters were fasting glycaemia $4.9 \mathrm{mmol} / \mathrm{L}$, total cholesterol $5.63 \mathrm{mmol} / \mathrm{L}(\mathrm{N}:<6.05)$, LDL cholesterol $3.61 \mathrm{mmol} / \mathrm{L}(\mathrm{N}:<4.20)$, HDL-cholesterol $1.61 \mathrm{mmol} / \mathrm{L}$ $(N:>1.05)$ and triglycerides $0.90 \mathrm{mmol} / \mathrm{L}(\mathrm{N}:<1.55)$.

His hormonal evaluations, performed at the age of 22 years, are presented in Table 1 . His plasma ACTH was $21 \mathrm{pg} / \mathrm{mL}(\mathrm{N}: 9-52)$ and his plasma renin was $18.1 \mathrm{pg} / \mathrm{mL}$ $(N: 3-30)$. His inhibin B was in the normal range: $154 \mathrm{pg} / \mathrm{mL}$ (N: 135-350), in favour of normal Sertoli cell function. His plasma FSH, LH, AMH and testosterone serum levels were within the normal range. Therefore, no testosterone 


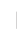

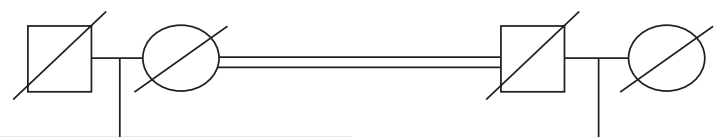

I

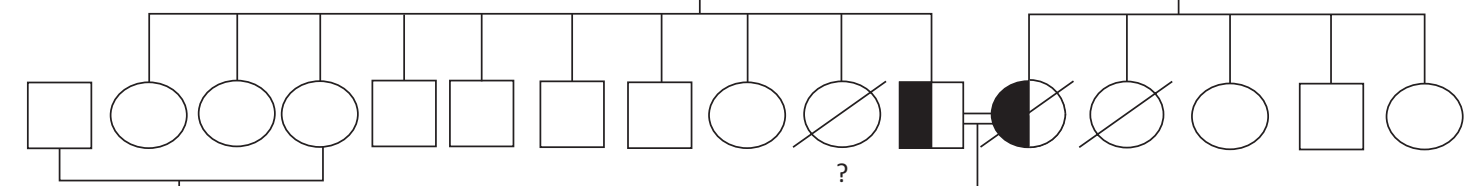

III
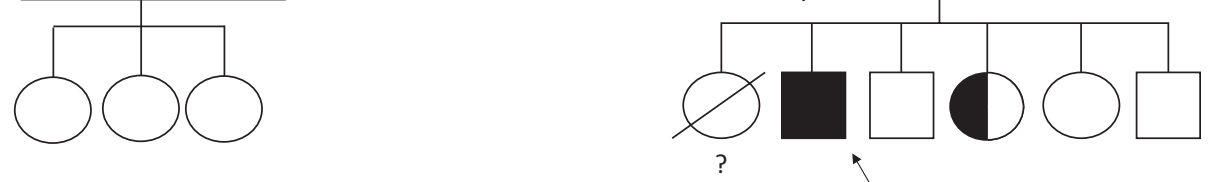

\section{Figure 2}

Family tree illustrating the index patient (III-5); he is the second child in a highly consanguineous family from Sri Lanka, his parents (II-10 and II-11) are first cousins, as well his grandparents (I-1 and I-2; I-3 and I-4 respectively). Their first daughter (III-4) died at birth in Sri Lanka, probably from acute adrenal salt wasting. Black box indicates the HSD3B2 687del27 homozygous mutation. Both parents (II-10 and II-11) were found to be heterozygous carrier for this mutation, as well as the patient's youngest sister (III-4).

treatment was administered to the patient. LC-MS/MS steroids profile analysis showed that 11betahydroxyandrostenedione (11OHA4) plasma levels were below the detection limit ( $N$ : 3-10 nmol/L).

His sperm parameters are reported in Table 2. Briefly, his sperm count was normal, as well as the percentage of sperm with typical morphology. The vitality was subnormal. For ethical reasons, testicular histology was not performed. However, sperm cryopreservation was proposed and the patient agreed to perform sperm banking.

Table 1 Hormonal status at age 22 years.

\begin{tabular}{l} 
Hormonal levels \\
\hline Pregnenolone (nmol/L) \\
$170 H$-pregnenolone (nmol/L) \\
Progesterone (nmol/L) \\
$170 H$-progesterone (nmol/L) \\
Deoxycorticosterone (nmol/L) \\
11-deoxycortisol (nmol/L) \\
Cortisol (nmol/L) \\
21 deoxycortisol (nmol/L) \\
Corticosterone (nmol/L) \\
Aldosterone (nmol/L) \\
DHEA (nmol/L) \\
Androstenedione (nmol/L) \\
11 betahydroxy- \\
androstenedione (nmol/l) \\
Total testosterone (nmol/L) \\
FSH (UI/L) \\
LH (Ul/L) \\
Inhibin B (pg/mL) \\
AMH (pmol/L)
\end{tabular}

\begin{tabular}{|c|c|}
\hline & Normal values \\
\hline 1.79 & $<6.3$ \\
\hline 4.38 & $<6$ \\
\hline 0.022 & $<0.6$ \\
\hline 0.022 & $1.2-7.6$ \\
\hline 0.009 & $0.3-4$ \\
\hline 0.006 & $<3$ \\
\hline 0.039 & $212-607$ \\
\hline$<0.01$ & $0.69-6.93$ \\
\hline 0.01 & 1.4-35 \\
\hline 0.011 & $<0.4$ \\
\hline 6.48 & $3.5-52$ \\
\hline 1.46 & $0.9-7$ \\
\hline$<3$ & $3-10$ \\
\hline 13.82 & $9-38$ \\
\hline 3.6 & $1.4-18.1$ \\
\hline 4.8 & $1.5-9.3$ \\
\hline 139 & $135-350$ \\
\hline 24 & $12-87$ \\
\hline
\end{tabular}

Hormonal adult status under treatment with hydrocortisone $(30 \mathrm{mg}$ per day) and fludrocortisone (75 mg per day). OH stands for hydroxyl.

\section{Discussion}

We report hormonal evaluation and normal sperm parameters in a $46, \mathrm{XY}$ patient, carrying a severe $H S D 3 B 2$ mutation.

Concerning steroidogenesis, the fetal consequences of the mutant protein on the genital tubercle are sexually dimorphic: testosterone and consequently dihydrotestosterone levels are lacking in a 46,XY foetus, but are in excess in $46, \mathrm{XX}$. This may be due to the fact that peripheral conversion of adrenal and gonadal DHEA caused by 3b-HSD1 is low during the fetal period (3). Hence, the external genitalia morphogenesis is impaired in males, who therefore may present undervirilisation, severe hypospadias and micropenis at birth. On the other hand, 46,XX patients are usually diagnosed during paediatric period, in front of premature acne or pubic hair with growth acceleration, due to DHEA accumulation above the enzymatic deficit and subsequent peripheral conversion to testosterone.

This patient has been followed in our reference centre of rare endocrine diseases from birth to the age of 24 years, on a yearly basis. Interestingly, although the patient's mutation is severe, his pubertal development was normal. In the literature, only 11 cases have reported pubertal status in male patients carrying HSD3B2 mutations (1, 2, 5, 11, 12, 13, 14, $15,16,17,18,19,20,21,29)$. Most of them entered puberty spontaneously. The explanation relies on a potential accumulation above the enzymatic deficit of delta 5-steroids precursors such as DHEA-S leading to testosterone biosynthesis via peripheral non-mutated HSD3B1 and HSD17B5 activity (Fig. 1).

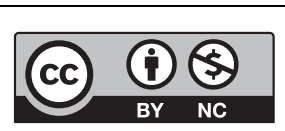

This work is licensed under a Creative Commons Attribution-NonCommercial 4.0 International License. 
Table 2 Patient' sperm parameters at the age of 22 years.

\begin{tabular}{|c|c|c|}
\hline & & Normal OMS value \\
\hline Volume (mL) & 3 & $>1.5$ \\
\hline $\mathrm{pH}$ & 7.9 & $>7.2$ \\
\hline Concentration (M/mL) & 57.6 & $>15$ \\
\hline Numeration (M) & 172.8 & $>39$ \\
\hline Vitality (\%) & 41 & $>58$ \\
\hline \multicolumn{3}{|l|}{ Mobility (\%) } \\
\hline Progressive motility (PR) & 20 & $>32$ \\
\hline Total motility (PR+NP) & 40 & $>40$ \\
\hline \multicolumn{3}{|l|}{ Cytogram } \\
\hline Typical form (\%) & $21 \%$ & $>4$ \\
\hline Abnormal acrosome & $36 / 48$ & - \\
\hline Abnormal flagella & $06 / 10$ & - \\
\hline
\end{tabular}

Some patients in the literature have been treated with intra-muscular testosterone injections. The main goal of this treatment is to increase the patient's testosterone level and therefore abolish the postpubertal gonadotropin contribution to oestrogens production, in order to prevent gynaecomastia (3). Indeed, gynaecomastia has been previously reported in several adult patients with $H S D 3 B 2$ mutation $(3,15)$. However, our patient did not present any gynaecomastia. His oestradiol levels remained within the normal male adult range, as well as his testosterone levels. The origin of testosterone in adult patients with HSD3B2 mutations is still debated. A first hypothesis relies on the fact that testosterone levels are secondary to the conversion of high delta 5-steroids, originating from the testis. Indeed, elevated testosterone levels have been described in the spermatic veins of HSD3B2 mutated patients (18). Intratesticular delta5-steroids could be converted to delta4 steroids by a compensatory isoenzyme, such as 3b-HSD1. Indeed, in vitro study of the 3b-HSD1 isoenzyme's activity is 5-fold higher than the enzymatic activity of 3b-HSD2. However, the presence of 3b-HSD1 iso-enzyme in testes is still debated. Indeed, an immuno-histochemical analysis for 3b-HSD2, as well as a western blot analysis for HSD3B2 revealed the absence of 3b-HSD2 expression in testis of a mutated patient (21). As the antibody used was not specific for the human type 2 isoenzyme, the authors made the hypothesis that HSD3B1 was also absent from testes.

A second potential source of testosterone in patients with HSD3B2 mutations is a peripheral conversion of adrenal steroids. Interestingly, in the current patient, LC-MS/MS steroids profile revealed that 11betahydroxyandrostenedione (11OHA4) was undetectable. Since the primary source of $11 \mathrm{OHA} 4$ is the adrenals and that 11OHA4 is metabolised through CYP11B1 activity, the absence of 11OHA4 is in accordance with a complete 3b-HSD deficit (22). Therefore, testosterone in our patient probably originates from testicular production.

Fertility of male patients with HSD3B2 mutations has been poorly evaluated (Table 3 ). Only one case has been reported as fathering two children (3). However, no sperm analysis, or genetic testing, has been performed in the children to prove his paternity.

Spermogram was reported in a single publication, in a patient carrying a severe HSD3B2 mutation (A10E) (11). Although his puberty had been normal and he had no past history of cryptorchidism, azoospermia as well as testicular adrenal rests tumours (TART) were observed (11). Recently,

Table 3 Types of HSD3B2 mutations, adrenal phenotypes, gonadal phenotypes, presence of gynaecomastia, sperm parameters and histology of male patients reported in the literature, compared to our patient's phenotype.

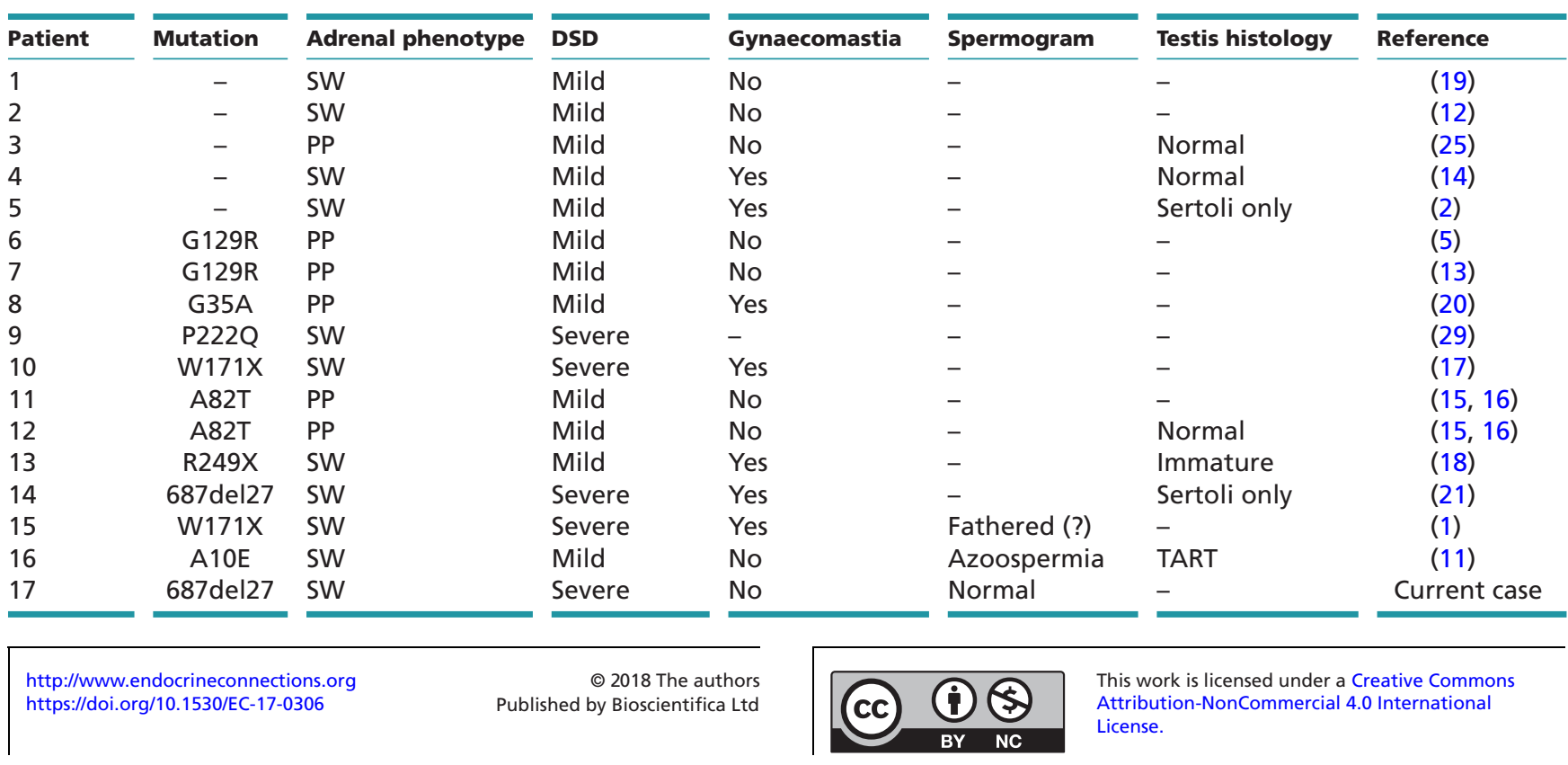


11OHA4 serum levels have been linked to the presence of TARTs, in patients with 21-hydroxylase/CYP21A2 deficiency $(23,24)$. Interestingly, 11 OHD4 plasma level was undetectable in our patient, in accordance with the absence of TART in his testes.

Our review of the literature identified 7 cases with testicular histology (Table 3). Among the 3 patients without a proven mutation, 2 had normal Leydig cells as well as seminiferous tubules with complete spermatogenesis including spermatozoa in their lumen and one had a Sertoli cell only syndrome. Among the 4 patients with a proven HSD3B2 mutation, testes histology was normal in one patient, one had immature spermatogenesis and one had TARTs with azoospermia (11). The remaining patient, carrying the same mutation as the one found in our patient, had a Sertoli cell only phenotype in most seminiferous tubules, only few tubules with some spermatogonia and arrested spermatogenesis, thus suggesting that he is unlikely to be fertile (21).

As this patient and the one we report, both originate from Sri Lanka, the question arises whether they could be related. However, our patient was not aware of any other member with the same disease outside his close family.

The data reported in the literature are in contrast with our results. Indeed, our patient presents normal sperm numeration as well as normal morphology, and sperm vitality is subnormal. Therefore, his sperm parameters are in favour of potential fertility. Several hypotheses may explain those discrepancies. First of all, Burckhardt's patient had a history of bilateral cryptorchidism (21). During childhood, his testes remained unpalpable and orchidopexy was performed at the age of 15 years. A previous history of cryptorchidism is known to be directly related to altered sperm production, as described in patients with hypogonadotropic hypogonadism (26). A second hypothesis relies on the fact that Burckhardt's patient had a severe syndrome including psychomotor retardation and severe neurological alteration. Atrophic basal ganglia had been identified on magnetic resonance imaging. Therefore, this patient might have a second disease, potentially altering his sperm production.

Sperm production of our patient is normal. This may be due to his treatment's compliance. Indeed, it has been described in patients with CYP21 classic congenital adrenal hyperplasia, that the presence of TARTs (27) is related to high ACTH plasma levels and therefore poor compliance (28). The presence of TARTs is involved in male infertility (27). We have been able to show that testosterone serum level in our patient has always been in the normal range from puberty up to his early adulthood. Hence, we can speculate that his hydrocortisone compliance could have had a beneficial influence on his spermatogenesis. His sperm numeration and morphology were normal, probably due to the absence of cryptorchidism, absence of TART as well as normal oestrogen and testosterone levels.

Because of potential further sperm decay, as described by Alos and coworkers in a patient with TART carrying a severe HSD3B2 mutation (A10E), sperm cryopreservation was proposed to our patient and immediately performed since he did not wish to father a child at the time of his evaluation (11). As the transmission pattern is autosomal recessive, the patient was informed that his future partner would have to be tested for HSD3B2 gene mutation.

\section{Conclusion}

Congenital adrenal hyperplasia due to HSD3B2 gene mutations (ORPHA90791) is an extremely rare form of congenital adrenal hyperplasia disease. In the severe form, the phenotype leads to neonatal salt wasting and severe male virilisation deficit. Our study illustrates the fact that fertility remains possible, even in front of a severe enzyme deficit, thus giving unsuspected opportunities of paternity to patients with severe HSD3B2 mutations.

\section{Declaration of interest}

The authors declare that there is no conflict of interest that could be perceived as prejudicing the impartiality of the research reported.

\section{Funding}

This research did not receive any specific grant from any funding agency in the public, commercial or not-for-profit sector.

\section{Author contribution statement}

Written informed consent has been obtained from the patient for publication of the submitted article and accompanying images.

\section{Acknowledgements}

The authors are grateful to Dr Marie-France Portnoï for cytogenetic analysis in Trousseau Hospital, Dr Jérome Guechot, Dr Antonin Lamazière, Dr Thibaut Eguether for LC-MS/MS measurements in Saint Antoine Hospital, and to the patient for his consent.

\section{References}

1 Rhéaume E, Simard J, Morel Y, Mebarki F, Zachmann M, Forest MG, New MI \& Labrie F. Congenital adrenal hyperplasia due to point mutations in the type II 3 beta-hydroxysteroid dehydrogenase gene.
This work is licensed under a Creative Commons Attribution-NonCommercial 4.0 International License. 
Nature Genetics 19921 239-245. (https://doi.org/10.1038/ng0792239)

2 Schneider G, Genel M, Bongiovanni AM, Goldman AS \& Rosenfield RL. Persistent testicular delta5-isomerase-3betahydroxysteroid dehydrogenase (delta5-3beta-HSD) deficiency in the delta5-3beta-HSD form of congenital adrenal hyperplasia. Journal of Clinical Investigation $1975 \mathbf{5 5}$ 681-690. (https://doi.org/10.1172/ JCI107977)

3 Morel Y, Roucher F, Plotton I, Simard J \& Coll M. 3 $\beta$-hydroxysteroid dehydrogenase deficiency. In Genetic Steroid Disorders, ch 3F, pp 99-110. Ed P Academic. New York: Elsevier, 2014.

4 Fluck CE. Steroidogenesis of the testis - new genes and pathways. Annales d'Endocrinologie 201475 40-47. (https://doi.org/10.1016/j. ando.2014.03.002)

5 Moisan AM, Ricketts ML, Tardy V, Desrochers M, Mébarki F, Chaussain JL, Cabrol S, Raux-Demay MC, Forest MG, Sippell WG, et al. New insight into the molecular basis of $3 \beta$-hydroxysteroid dehydrogenase deficiency: identification of eight mutations in the HSD3B2 gene in eleven patients from seven new families and comparison of the functional properties of twenty-five mutant enzymes. Journal of Clinical Endocrinology and Metabolism $1999 \mathbf{8 4}$ 4410-4425. (https://doi.org/10.1210/jcem.84.12.6288)

6 Kulle A, Krone N, Holterhus PM, Schuler G, Greaves RF, Juul A, De Rijke YB, Hartmann MF, Saba A, Hiort O, et al. Steroid hormone analysis in diagnosis and treatment of DSD: position paper of Eu COST action BM 1303 'DSDnet'. European Journal of Endocrinology 2017176 P1-P9. (https://doi.org/10.1530/EJE-160953)

7 Giton F, Guéchot J \& Fiet J. Comparative determinations of non SHBG-bound serum testosterone, using ammonium sulfate precipitation, Concanavalin A binding or calculation in men. Steroids 201277 1306-1311. (https://doi.org/10.1016/j.steroids.2012.04.009)

8 Coutant R, Biette-Demeneix E, Bouvattier C, Bouhours-Nouet N, Gatelais F, Dufresne S, Rouleau S \& Lahlou N. Baseline inhibin $\mathrm{B}$ and anti-Mullerian hormone measurements for diagnosis of hypogonadotropic hypogonadism (HH) in boys with delayed puberty. Journal of Clinical Endocrinology and Metabolism 201095 5225-5232. (https://doi.org/10.1210/jc.2010-1535)

9 Fiet J, Le Bouc Y, Ome E, Echot G, Elin N, Maubert MA, Farabos D \& Lamazì Ere A. A liquid chromatography/tandem mass spectometry profile of 16 serum steroids, including 21-deoxycortisol and 21-deoxycorticosterone, for management of congenital adrenal hyperplasia Journal of the Endocrine Society 20171 186-201. (https:// doi.org/10.1210/js.2016-1048)

10 Cooper TG, Noonan E, von Eckardstein S, Auger J, Baker HWG, Behre HM, Haugen TB, Kruger T, Wang C, Mbizvo MT, et al. World Health Organization reference values for human semen characteristics. Human Reproduction Update 201016 231-245. (https://doi.org/10.1093/humupd/dmp048)

11 Alos N, Moisan AM, Ward L, Desrochers M, Legault L, Leboeuf G, Van Vliet G \& Simard J. A novel A10E homozygous mutation in the HSD3B2 gene causing severe salt-wasting 3 $\beta$-hydroxysteroid dehydrogenase deficiency in 46,XX and 46,XY French-Canadians: evaluation of gonadal function after puberty. Journal of Clinical Endocrinology and Metabolism 200085 1968-1974. (https://doi. org/10.1210/jc.85.5.1968)

12 Bin-Abbas BS, Sakati NA \& Al-Ashwal AA. Congenital adrenal hyperplasia due to 3 beta-hydroxysteroid dehydrogenase type II deficiency in 4 Saudi children. Long term follow up. Saudi Medical Journal 200425 1293-1295.

13 Chang YT, Kulin HE, Garibaldi L, Suriano MJ, Bracki K \& Pang S Hypothalamic-pituitary-gonadal axis function in pubertal male and female siblings with glucocorticoid-treated nonsalt-wasting 3 beta-hydroxysteroid dehydrogenase deficiency congenital adrenal hyperplasia. Journal of Clinical Endocrinology and Metabolism $1993 \mathbf{7 7}$ 1251-1257. (https://doi.org/10.1210/jcem.77.5.8077318)
14 Jänne O, Perheentupa J, Viinikka L \& Vihko R. Testicular endocrine function in a pubertal boy with 3beta-hydroxysteroid dehydrogenase deficiency. Journal of Clinical Endocrinology and Metabolism 197439 206-209. (https://doi.org/10.1210/jcem-39-1-206)

15 Mendonca BB, Bloise W, Arnhold IJP, Batista MC, Toledo SP, Drummond MCF, Nicolau W \& Mattar E. Male pseudohermaphroditism due to nonsalt-losing 3 $\beta$-hydroxysteroid dehydrogenase deficiency: gender role change and absence of gynecomastia at puberty. Journal of Steroid Biochemistry 198728 669-675. (https://doi. org/10.1016/0022-4731(87)90396-7)

16 McCartin S, Russell AJ, Fisher RA, Wallace AM, Arnhold IJ, Mason JI, Varley J, Mendonca BB \& Sutcliffe RG. Phenotypic variability and origins of mutations in the gene encoding 3beta-hydroxysteroid dehydrogenase type II. Journal of Molecular Endocrinology 200024 75-82. (https://doi.org/10.1677/jme.0.0240075)

17 Parks GA, Bermudez JA, Anast CS, Bongiovanni AM \& New MI. Pubertal boy with the 3 $\beta$-Hydroxy steroid dehydrogenase defect. Journal of Clinical Endocrinology and Metabolism 1971 33 269-278. (https://doi.org/10.1210/jcem-33-2-269)

18 Yoshimoto M, Kawaguchi T, Mori R, Kinoshita E, Baba T, Tajima T, Fujieda K, Suzuki T \& Sasano H. Pubertal changes in testicular 3 beta-hydroxysteroid dehydrogenase activity in a male with classical 3 beta-hydroxysteroid dehydrogenase deficiency showing spontaneous secondary sexual maturation. Hormone Research 199748 83-87. (https://doi.org/10.1159/000185492)

19 Kenny FM, Reynolds JW \& Green OC. Partial 3 -hydroxysteroid dehydrogenase (3 -HSD) deficiency in a family with congenital adrenal hyperplasia: evidence for increasing 3 -HSD activity with age. Pediatrics 197148 756-765.

20 Benkert AR, Young M, Robinson D, Hendrickson C, Lee PA \& Strauss KA. Severe salt-losing 3 -hydroxysteroid dehydrogenase deficiency: treatment and outcomes of HSD3B2 c.35G $>$ A homozygotes. Journal of Clinical Endocrinology and Metabolism 2015 100 1105-1115. (https://doi.org/10.1210/jc.2015-2098)

21 Burckhardt MA, Udhane SS, Marti N, Schnyder I, Tapia C, Nielsen JE, Mullis PE, De Meyts ER \& Flück CE. Human 3 $\beta$-hydroxysteroid dehydrogenase deficiency seems to affect fertility but may not harbor a tumor risk: lesson from an experiment of nature. European Journal of Endocrinology 2015173 K1-K12. (https://doi.org/10.1530/EJE-150599)

22 Bloem LM, Storbeck KH, Schloms L \& Swart AC. 11ß-hydroxyandrostenedione returns to the steroid arena: biosynthesis, metabolism and function. Molecules $2013 \mathbf{1 8}$ 13228-13244. (https://doi.org/10.3390/molecules181113228)

23 Turcu AF, Nanba AT, Chomic R, Upadhyay SK, Giordano TJ, Shields JJ, Merke DP, Rainey WE \& Auchus RJ. Adrenal-derived 11-oxygenated 19-carbon steroids are the dominant androgens in classic 21-hydroxylase deficiency. European Journal of Endocrinology 2016174 601-609. (https://doi.org/10.1530/EJE-15-1181)

24 Turcu AF, Mallappa A, Elman MS, Avila NA, Marko J, Rao H, Tsodikov A, Auchus RJ \& Merke DP. 11-oxygenated androgens are biomarkers of adrenal volume and testicular adrenal rest tumors in 21-hydroxylase deficiency. Journal of Clinical Endocrinology and Metabolism 2017102 2701-2710. (https://doi.org/10.1210/jc.2016-3989)

25 Rosenfield RL, Barmach de Niepomniszsze A, Kenny FM \& Genel M. The response to human chorionic gonadotropin (HCG) administration in boys with and without delta5-3betahydroxysteroid dehydrogenase deficiency. Journal of Clinical Endocrinology and Metabolism 197439 370-374. (https://doi. org/10.1210/jcem-39-2-370)

26 Pitteloud N, Hayes FJ, Dwyer A, Boepple PA, Lee H \& Crowley WF. Predictors of outcome of long-term GnRH therapy in men with idiopathic hypogonadotropic hypogonadism. Journal of Clinical Endocrinology and Metabolism 200287 4128-4136. (https://doi. org/10.1210/jc.2002-020518)

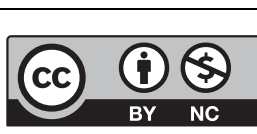

This work is licensed under a Creative Commons Attribution-NonCommercial 4.0 International License. 
27 Bouvattier C, Esterle L, Renoult-Pierre P, De La Perriere AB, Illouz F, Kerlan V, Pascal-Vigneron V, Drui D, Christin-Maitre S, Galland F, et al. Clinical outcome, hormonal status, gonadotrope axis, and testicular function in 219 adult men born with classic 21-hydroxylase deficiency. A French national survey. Journal of Clinical Endocrinology and Metabolism 2015100 2303-2313. (https://doi.org/10.1210/jc.2014-4124)

28 Speiser PW, Azziz R, Baskin LS, Ghizzoni L, Hensle TW, Merke DP, Meyer-Bahlburg HFL, Miller WL, Montori VM, Oberfield SE, et al. Congenital adrenal hyperplasia due to steroid 21-hydroxylase deficiency: an Endocrine Society clinical practice guideline. Journal of Clinical Endocrinology and Metabolism 201095 4133-4160. (https:// doi.org/10.1210/jc.2009-2631)

29 Mermejo LM, Elias LL, Marui S, Moreira AC, Mendonca BB \& de Castro M. Refining hormonal diagnosis of type II 3betahydroxysteroid dehydrogenase deficiency in patients with premature pubarche and hirsutism based on HSD3B2 genotyping. Journal of Clinical Endocrinology and Metabolism 200590 1287-1293. (https:// doi.org/10.1210/jc.2004-1552)

Received in final form 9 January 2018

Accepted 2 February 2018

Accepted Preprint published online 2 February 2018 http://www.endocrineconnections.org https://doi.org/10.1530/EC-17-0306 (c) 2018 The authors Published by Bioscientifica Ltd

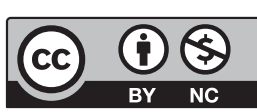

This work is licensed under a Creative Commons Attribution-NonCommercial 4.0 International License. 